\title{
PENGARUH PENGGANTIAN SEBAGIAN SEMEN DENGAN ABU TERBANG (FLY ASH) DAN ABU CANGKANG LOKAN TERHADAP KUAT TEKAN PAVING BLOCK
}

\author{
Marwan $^{1)}$, Fepy Supriani ${ }^{2)}$, YuzuarAfrizal ${ }^{3)}$ \\ ${ }^{1)}$ Alumni Program Studi Teknik Sipil Fakultas Teknik UNIB \\ Jl. W.R. Supratman, Kandang Limun,Bengkulu 38371, \\ e-mail : marwan.mardian@gmail.com \\ ${ }^{2), 3)}$ Staf Pengajar Program Studi Teknik Sipil UNIB, Bengkulu
}

\begin{abstract}
Abstrak
Paving block digunakan untuk memenuhi kebutuhan akan perkerasan permukaan. Penelitian ini menggunakan limbah abu cangkang lokan dan fly ash sebagai bahan pengganti semen dalam pembuatan paving block. Abu cangkang lokan dan fly ash mengandung kalsium oksida $(\mathrm{CaO})$ dan silika oksida $\left(\mathrm{SiO}_{2}\right)$ yang dapat mengganti dan menguatkan komposisi kimia semen. Variasi penggantian sebanyak 2,5\%,5\%,7,5\% dan $10 \%$ dibandingkan dengan kuat tekan paving block normal (0\%). Benda uji berjumlah 75 sampel berbentuk segi empat dengan ukuran panjang $20 \mathrm{~cm}$, lebar $10 \mathrm{~cm}$ dan ketebalan $6 \mathrm{~cm}$. Pembuatan paving block menggunakan metode pengerjaan konvensional. Hasil pengujian kuat tekan umur 7 hari, 14 hari dan 28 hari untuk setiap variasi meningkat sampai pada variasi 7,5\% dan turun di $10 \%$. Hasil nilai kuat tekan rata-rata terbesar terjadi pada variasi penggantian 7,5\% yaitu pada umur 7 hari sebesar 31,19 $\mathrm{MPa}$, umur 14 hari sebesar 33,55 $\mathrm{MPa}$ dan umur 28 hari sebesar $34,74 \mathrm{MPa}$. Persentase peningkatan kuat tekan tertinggi terjadi pada umur 28 hari dengan kenaikan sebesar 23,19\%.
\end{abstract}

Kata kunci :paving block, fly ash, cangkang lokan, kuat tekan.

\begin{abstract}
Paving block is used to fill the needs of surface pavement. This research uses waste of sea shell ash and fly ash as cement substitute material in the manufacture of paving blocks. Sea shell ash and fly ash containing calcium oxide $(\mathrm{CaO})$ and silica oxide $\left(\mathrm{SiO}_{2}\right)$ that can replace and strengthen the chemical composition of cement. Variations of replacement much as $2.5 \%, 5 \%$, $7.5 \%$ and $10 \%$ compared to normal compressive strength of the paving block (0\%). Test specimen numbered 75 samples of rectangular with a length of $20 \mathrm{~cm}$, width $10 \mathrm{~cm}$ and a thickness of $6 \mathrm{~cm}$. Manufacture of paving blocks using conventional construction methods. The results of compressive strength testing of the age of 7 days, 14 days and 28 days for any variations on the variations increase to $7.5 \%$ and down 10\%. The results of the compressive strength largest average variation occurs in the replacement of $7.5 \%$ ie at the age of 7 days of $31.19 \mathrm{MPa}$, aged 14 days amounted to $33.55 \mathrm{MPa}$ and 28 days amounted to $34.74 \mathrm{MPa}$. The percentage increase was highest compressive strength at 28 days with an increase of $23.19 \%$.
\end{abstract}

Keywords :paving block, fly ash, sea shell ash, compressive strength 


\section{PENDAHULUAN}

Paving block merupakanbahanbangunan yang dibuatdaricampuran semen Portland atau bahan perekat hidrolis, air dan agregat dengan atau tanpa bahan tambahan lainnya yang tidakmengurangimutu (SNI 03-06911996).Paving block juga merupakan salah satu alternatif pilihan untuk lapis perkerasan permukaan tanah, kemudahan dalam pemasangan, perawatan relatif murah serta memenuhi aspek keindahan.

Paving block mempunyai banyak kelebihan baik dari seg ipembuatan yang tidak memerlukan alat berat, ketahanan beban statis maupun dinamik dan pemasangan yang dapat dibongkar kembali (Sebayangdkk, 2011). Keunggulan lainnya dari paving block ialah daya serap air yang baik sehingga dapat menjaga ketersediaan air tanah yang dapat digunakan dalam kehidupan sehari-hari.

Abu Terbang (fly ash) merupakan limbah yang dapat mengakibatkan pencemaran lingkungan dan pemanfaatan fly ash adalah salah satu usaha untuk menanggulangi masalah lingkungan. Fly ash mengandung silika oksida ( $\mathrm{SiO} 2)$ yang merupakan salah satu bahan penyusun pembuatan semen. Fly ash memiliki sifat pozzoland dan dapat bereaksi dengan kapur pada suhu kamar dengan menggunakan media air dan membentuk senyawa yang bersifat mengikat (Armeyn, 2014).

Cangkang lokan yang diambil isinya untuk dikonsumsi sedangkan cangkang dari lokan tersebut hanya menjadi limbah dan belum dimanfaatkan secara maksimal oleh masyarakat. Cangkang lokan mengandung $\mathrm{CaCO}_{3}$ yang jika dipanaskan akan menjadiCaO dan melepaskan $\mathrm{CO}_{2}$ keudara, sementara $\mathrm{CaO}$ dan $\mathrm{Si}$ adalah bahan utama pembuatan semen selainFe $\mathrm{O}_{3}$ dan $\mathrm{Al}$ (Wahyunidkk, 2013).
Tabel 1 Komposisi Kimia Abu Cangkang Lokan

\begin{tabular}{|c|l|c|}
\hline no & Komponen & \multicolumn{2}{|c|}{$\begin{array}{c}\text { Kandungan } \\
\%\end{array}$} \\
\hline 1 & Kalsium Oksida $(\mathrm{CaO})$ & 66,7 \\
\hline 2 & Silika Oksida $\left(\mathrm{SiO}_{2}\right)$ & 7,88 \\
\hline 3 & $\begin{array}{l}\text { Aluminium Oksida } \\
\left(\mathrm{Al}_{2} \mathrm{O}_{3}\right)\end{array}$ & 1,25 \\
\hline 4 & Besi Oksida $\left(\mathrm{fe}_{2} \mathrm{O}_{3}\right)$ & 0,03 \\
\hline 5 & $\begin{array}{l}\text { Magnesium } \mathrm{Oksida} \\
(\mathrm{MgO})\end{array}$ & 22,2 \\
\hline
\end{tabular}

Sumber: Andre, 2012.

Berdasarkan kandungan yang dimiliki oleh abu terbang dan abu cangkang lokan terdapat beberapa kemiripan dengan kandungan yang terdapa tpada semen Portland. Semen Portland sendiri dihasilkan denganvmenggiling terak yang terutama terdiri dari kalsium silika dan digiling bersama-sama senyawa kalsium sulfat (SNI 15-2049-2004). Menurut Nursal dan Mahmud (2013) kandunganKalsium Oksida (CaO) $62,1 \%$ danSilika Oksida $\left(\mathrm{SiO}_{2}\right) 22 \%$.

Hendriansyah (2016) melakukan penelitian tentang penambahan abu cang kang lokan terhadap kuat tekanpaving block dengan variasi sebesar $5 \%, 10 \%, 15 \%$, dan $20 \%$ berdasarkan berat semen. Hasil kuat tekan terbesar paving block terdapat pada penambahan abu cangkang lokan dengan variasi $15 \%$ padaumur 28 hari sebesar 34,47 MPa.

Rumusan masalah pada penelitian ini adalah bagaimana jika dilakukan pergantian sebagian semen dengan campuran abu terbang dan abu cangkang lokan terhadap kekuatan paving block.

Penelitian ini bertujuan untuk mengetahui pengaruh penggantian sebagian semen dengan fly ash dan abu cangkang lokan pada pembuatan paving block dengan metode konvensional terhadap nilai kuat tekan paving block. Sampel benda uji yang dicetak berbentuk segi empat dengan variasi penggantian sebagian semen sebanyak 2,5\%, $5 \%, 7,5 \%$ dan $10 \%$ dari berat semen. 
Abu cangkang lokan yang digunakan sebagai bahan pengganti sebagian semen sebanyak $70 \%$ dan fly ash sebanyak $30 \%$. Penggantian persentase cangkang lokan yang lebih banyak dari fly ash didasari dari kandungan kalsium oksida $(\mathrm{CaO})$ dan silika oksida ( $\mathrm{SiO} 2)$ yang digunakan dalam bahan penyusun pembuatan semen.

\section{METODE PENELITIAN}

Tahapan pelaksanaan penelitian meliputi pemeriksaan bahan campuran mortar dengan melakukan uji fisis, perhitungan kebutuhan bahan untuk adukan paving block, pembuatan sampel (benda uji), dan perawatan. Tahap selanjutnya adalah pelaksanaan pengujian kuat tekan pada paving block.

\section{Persiapan Bahan}

Pencetakan benda uji dilakukan setelah persiapan bahan, bahan-bahan yang digunakan dipersiapkan sebagai berikut :

1. Abu terbang (fly ash)

Fly Ash yang digunakan adalah yang langsung masuk ke tempat penampungan dengan lolos saringan No. 100. Mulyati (2015). Fly ashdalampenelitian adalah sisa pembakaran batubara PT. Prima Naya yang merupakan perusahaan Pembangkit Listrik Tenaga Uap (PLTU) Kabupaten Lahat, Sumatra Selatan. Fly ash yang digunakan disaring kembali secara manual dengan lolos saringan No.100. Abu terbang (fly ash) dapatdilihatpada Gambar1.

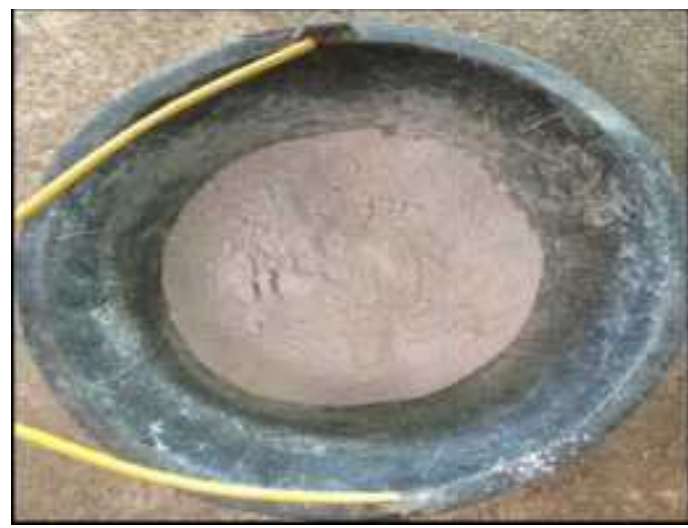

Gambar 1. Abu Terbang (Fly Ash)
2. Abu cangkang lokan.

Cangkang lokan diperoleh dari limbah Pasar Panorama, Kota Bengkulu. Cangkanglokandibersihkan dan dikeringkan kemudian dibakar dengan menggunakan tungku apiselamakurang lebih 30menit, kemudian ditumbuk, digiling dan disaring dengan menggunakan saringan No.100. Cangkang lokan dan abu cangkang lokan yang telah diproses dapatdilihatpadaGambar2 dan Gambar 3.

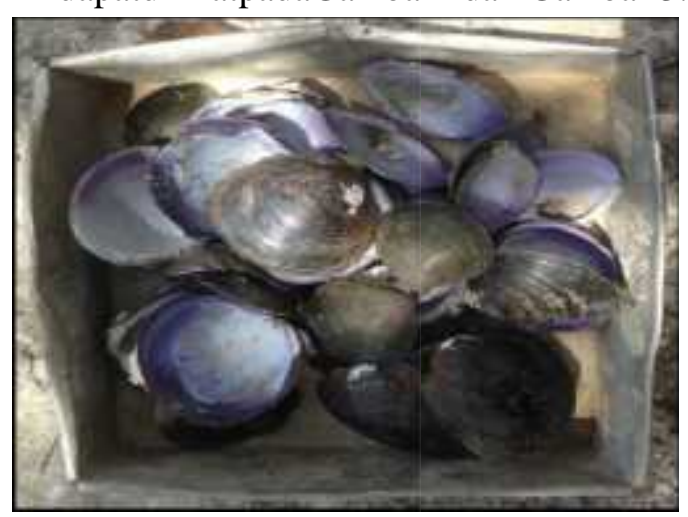

Gambar2 CangkangLokan

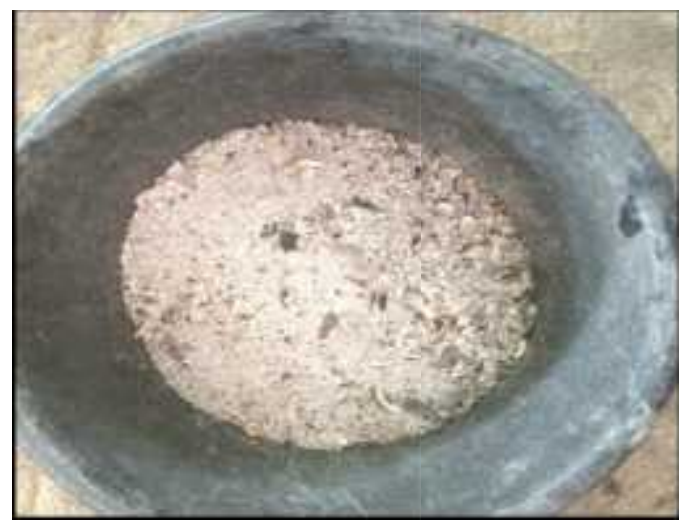

Gambar 3. Abu Cangkang Lokan

\section{Pemeriksaan Bahan Campuran}

Bahan campuran paving block terlebih dahulu dilakukan uji visual dan uji fisis sebagai pemeriksaan bahan yang digunakan. Uji visual dilakukan pada abu cangkanglokan dan fly ash dan juga dilakukan penyaringan dengan saringan No.100. 


\section{Pemeriksaan Agregat Halus dan Semen}

Pamungkas dan Hairunnisa (2007) menyatakan agregat halus adalah butiran-butiran mineral keras yang bentuknya mendekati bulat, tajam dengan ukuran butir sebagian besar terletak antara 0,07-5 mm

Pemeriksaan uji fisis yang dilakukan pada agregat halus adalah analisa saringan, kadar air, kadar lumpur, berat jenis, kadar organik dan berat isi. Agregat halus yang digunakan adalah pasir sungai yang diambil dari daerah sungai Ketahun Bengkulu Utara.Sedangkanpemeriksaan semen dilakukansecara visual, semen tidakbergumpal.

\section{Pembuatan Benda Uji}

Proses pada pembuatan paving block yang dilakukan memerlukan beberapa tahapan, adapun beberapa hal tahapan tersebut adalah sebagai berikut :

1. Bahan-bahan yang digunakan pada campurandalampembuatanpaving block dipersiapkan terlebih dahulu. Tahap persiapan dimulai dari pengumpulan bahan, pembakaran dan penumbukan cangkang lokan, penyaringan abu cangkang lokan dan fly ashhingga proses penimbangan bahan campuran.

2. Pasir, semen, abu cangkang lokan dan fly ash yang telah ditentukan takarannya berdasarkan berat yang telah dilakukan penimbangan kemudian dilakukan proses pencampuran bahan.

3. Bahan campuran yang telah ditentukan takarannya sesuai variasi penggantian sebagian semen yang digunakan kemudian diaduk merata. Campuran bahan yang telah diaduk merata kemudian ditambahkan air dan diaduk kembali hingga campuran merata dan siap untuk dilakukan proses pencetakan.
4. Pencetakan dilakukan dengan menggunakan alat gablokan.
5. Bahan yang telah dicampur dimasukkan kedalam cetakan dan dipadatkan dengan cara dipukul-pukul mengunakan alat pemukul. Bahan campuran dalam cetakan kemudian dilepas dengan cara cetakan dibalik dan cetakan diangkat secara perlahan-lahan.

6. Paving block yang telah tercetak kemudian dikeringkan dengan disimpan pada tempat yang teduh dan lembab.

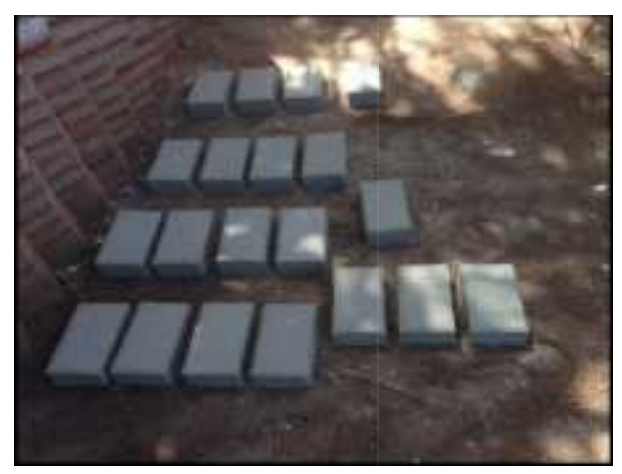

Gambar 4. Paving Block Setelah Pencetakan

\section{Perawatan Paving Block}

Paving block setelah pencetakan dilakukan proses perawatan terlebih dahulu sebelum tahap pengujian hingga mencapai umur 7 hari, 14 hari dan 28 hari. Paving block yang telah dilepas dari cetakan selama 24 jam dilakukan proses perawatan dengan direndam didalam air. Proses pengeringan dilakukan dengan cara didiamkan selama 24 jam setelah proses perendaman pada suhu ruangan baru kemudian dilakukan tahap pengujian gambar 5 . 


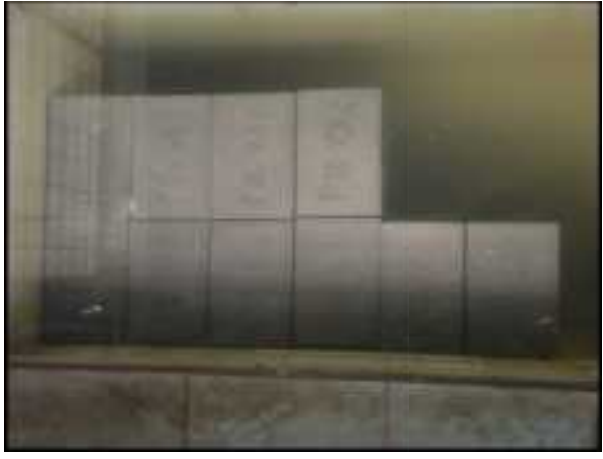

Gambar 5. Paving Block PadaSaat Perendaman

\section{Pengujian Kuat Tekan Paving Block}

Pengujian kuat tekan paving block sesuai dengan berdasarkan SNI 03-0691-1996. Pengujian kuat tekan dilakukan ketika paving block berumur 7 hari, 14 hari dan 28 hari. Benda uji tidak dilakukan proses pemotongan menjadi bentuk yang simetris dengan mempertahankan bentuk aslinya. Pengukuran dimensi dan penimbangan berat benda uji dilakukan terlebih dahulu. Alat yang digunakan pada pengujian paving block adalah alat uji kuat tekan (Compression Machine Hand Operated) berkapasitas 150 ton.

\section{Analisa Data}

Kuat tekan paving block adalah gaya maksimum persatuan luas yang bekerja pada benda uji paving block. Rumus perhitungan yang digunakan untuk mencari kuat tekan paving block menurut SNI 03-0691-1996.

$$
\text { Kuat Tekan }=\frac{P}{L}
$$

Keterangan :

$\mathrm{P}=$ Beban Tekan $(\mathrm{N})$.

$\mathrm{L}=$ Luas Bidang Tekan $\left(\mathrm{mm}^{2}\right)$.

Standar deviasi dapat menggambarkan seberapa besar perbedaan nilai sampel setiap individu terhadap nilai rata-ratanya. Nilai standar deviasi yang semakin kecil memberikan gambaran bahwa nilai titik data individu mendekati dengan nilai rata- ratanya. Sebaliknya semakin besar nilai standar deviasi maka semakin menjauhi dari nilai rata-ratanya. Rumus standar deviasi menurut SNI 03-6815-2002 tentang tata cara mengevaluasi hasil uji kekuatan beton.

$$
\mathrm{s}=\sqrt{\frac{\sum(x-\bar{x})^{2}}{n-1}}
$$

Keterangan:

$\bar{x}=$ Nilai rerata benda uji (MPa)

$\mathrm{x}=$ Nilai masing-masing benda uji dalam pengamatan tersebut $(\mathrm{MPa})$

$\mathrm{s}=$ Standar deviasi

$\mathrm{n}=$ Jumlah benda uji

\section{HASIL DAN PEMBAHASAN}

\section{Pemeriksaan Bahan Campuran}

Agregat halus yang digunakan dilakukan uji fisis untuk mengetahui kelayakan dari agregat itu sendiri dalam pembuatan paving block.Hasil ringkasan pemeriksaan agregat halus dapat dilihat pada Tabel 2 .

Tabel 2. Pemeriksaan Agregat Halus

\begin{tabular}{|l|c|}
\hline \multicolumn{1}{|c|}{ Keterangan } & $\begin{array}{c}\text { Agregat } \\
\text { Halus }\end{array}$ \\
\hline MHB & 2,62 \\
\hline Beratjenis & 2,66 \\
\hline Absorbsi $(\%)$ & 2,35 \\
\hline Beratisi $\left(\mathrm{kg} / \mathrm{dm}^{3}\right)$ & 1,54 \\
\hline Kadar air $(\%)$ & 2,56 \\
\hline Kadar lumpur $(\%)$ & 3,61 \\
\hline
\end{tabular}

Hasildari pengolahan cangkang lokan yang sudah dibersihkan dari kotoran yang menempel dan dibakar serta ditumbuk halus menjadi berbentuk abu. Abu cangkang lokan, fly ash dan semendilakukan uji visual tidak menggumpal dan memiliki kehalusan yang seragam. Abu cangkang lokan dan fly ash sebagai bahan pengganti sebagian semen kemudian dilakukan penyaringan dengan lolos saringan No.100.

Semen yang digunakan adalah PCC yang sesuai dengan standar SNI 15-7064-2004. 
Kemasan pada semen yang digunakan diamati secara visual dimana kemasan dalam keadaan tertutup dan tidak terdapat kerusakan pada segel maupun kantung.

\section{Pengujian Kuat Tekan Paving Block}

Pengujian kuat tekan paving block dilakukan pada umur 7 hari, 14 hari dan 28 hari setelah proses pencetakan berdasarkan SNI 030691-1996 tentang Bata Beton (Paving Block). Benda uji dilakukan pengujian kuat tekan dalam keadaan ukuran dimensi yang tidak dilakukan proses pemotongan menjadi bentuk ukuran dimensi yang simetris. Hasil pengujian dapat dilihat pada tabel 3 .

Tabel 3. Nilai Rata-Rata Kuat Tekan Paving

\begin{tabular}{|c|c|c|c|c|c|}
\hline \multirow[b]{3}{*}{$\mathrm{No}$} & \multirow[b]{3}{*}{ Kode } & & & & \\
\hline & & \multirow{2}{*}{$\begin{array}{c}\text { Kadar } \\
\text { AbuCang } \\
\text { kangLoka } \\
\text { n dan Fly } \\
\text { Ash }\end{array}$} & \multicolumn{3}{|c|}{$\begin{array}{l}\text { KuatTekan Rata-Rata } \\
\text { (MPa) }\end{array}$} \\
\hline & & & 7 hari & 14 hari & 28 har \\
\hline 1 & PB 0 & $0 \%$ & 25,64 & 27,37 & 28,20 \\
\hline 2 & PB 2,5 & $2,5 \%$ & 27,48 & 2857 & 31,91 \\
\hline 3 & PB 5 & $5 \%$ & 29,59 & 31,10 & 32,23 \\
\hline 4 & PB 7,5 & $7,5 \%$ & 31,19 & 33,10 & 34,74 \\
\hline 5 & PB 10 & $10 \%$ & 27.01 & 27,97 & 29,09 \\
\hline
\end{tabular}

Berdasarkan dari hasil pengujian terjadi peningkatan kuat tekan berturut-turut pada variasi $2,5 \%, 5 \%, 7,5 \%$ dan turun padavariasi $10 \%$. Hasil kuat tekan rata-rata terbesar paving block terdapat pada variasi 7,5\% yaitu pada umur 7 hari sebesar $31,19 \mathrm{MPa}$, umur 14 hari sebesar 33,55 $\mathrm{MPa}$ danumur 28 hari sebesar 34,74 MPa. Persentase peningkatan kuat tekan terbesar juga terjadi pada variasi 7,5\% yaitu sebesar 6,54 MPa atau 23,19\% terhadap kuat tekan paving block tanpa bahan penggantian sebagian semen.
Persentase peningkatan yang terjadi pada umur 7, 14 dan 28 hari dapat dilihat pada Gambar 6 dan Gambar 7 dan Gambar 8.

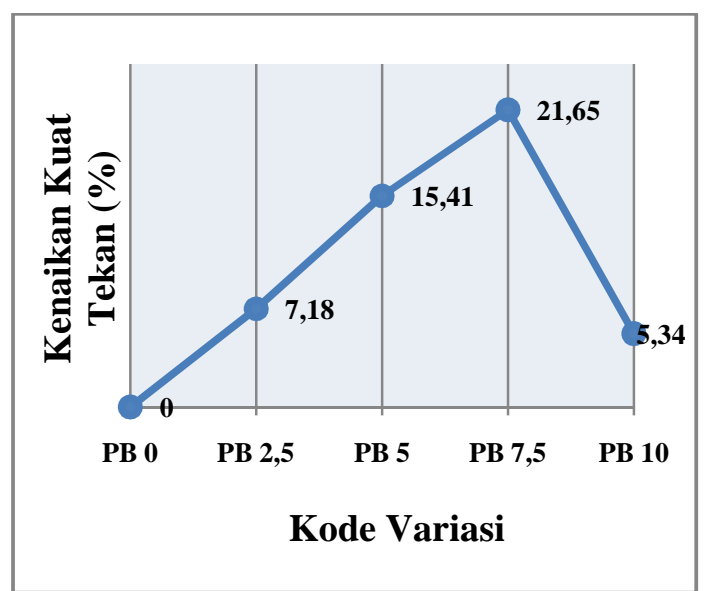

Gambar 6. Grafik Persentase Peningkatan Kuat Tekan Umur 7 Hari

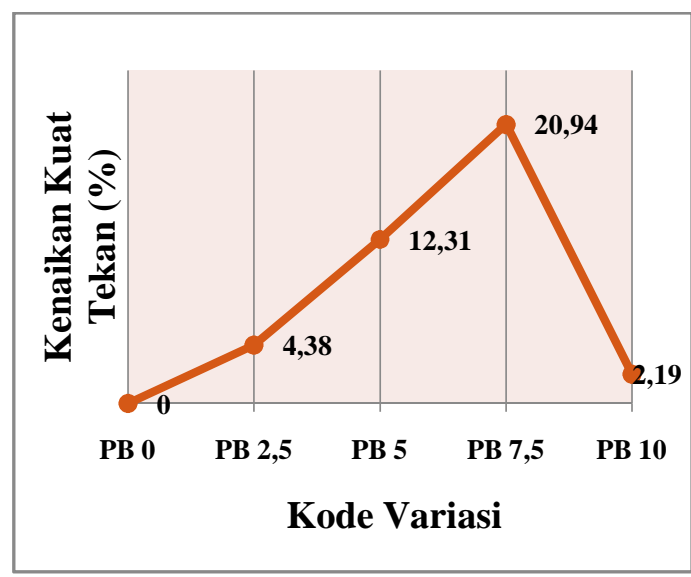

Gambar 7. Grafik Persentase Peningkatan Kuat Tekan Umur 14 Hari

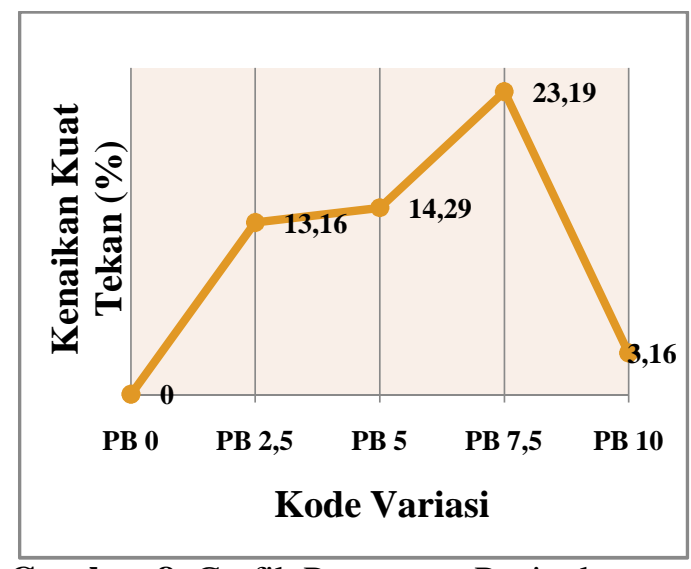

Gambar 8. Grafik Persentase Peningkatan Kuat Tekan 28 Umur Hari 
Berdasarkan persentase peningkatan kuat tekan yang terjadi pada umur 7 hari, 14 hari dan 28 hari. Komposisi kimia Abu cangkang lokan danfly ash dapat mengganti dan menguatkan kandungan yang terdapat pada semen, hal ini terlihat dengan peningkatan persentase kuat tekan dibandingkan dengan tanpa bahan pengganti.

Peningkatan terjadi berturut-turut pada variasi penggantiannya hanya saja pada variasi $10 \%$ mengalami penurunan, tetapi masih diatas kuat tekan normal. Hasil kuat tekan rata-rata terbesar paving block terdapat pada variasi $7,5 \%$ yaitu pada umur 7 hari sebesar 31,19 $\mathrm{MPa}$, umur 14 hari sebesar 33,55 $\mathrm{MPa}$ danumur 28 hari sebesar 34,74 $\mathrm{MPa}$. Persentase peningkatan kuat tekan terbesar terjadi pada variasi $7,5 \%$ yaitu sebesar 6,54 MPa atau 23,19\% terhadap kuat tekan paving block tanpa bahan penggantian sebagian semen.

Bahan abu cangkang lokan dan fly ash dapat dijadikan alternatif pilihan dalam pembuatan paving block. Kalsium oksida $(\mathrm{CaO})$ dan silika oksida $\left(\mathrm{SiO}_{2}\right)$ yang terkandung dalam abu cangkang lokan dan fly ash dapat mengganti dan menguatkan komposisi kimia semen. Penggantian sebagian semen pada variasi $2,5 \%, 5 \%$ dan7,5\% dapat digunakan pada pembuatan paving block karena mengalami peningkatan kuat tekan. Variasi $10 \%$ juga dapat digunakan sebagai bahan pengganti dalam pembuatan paving block, hanya saja kuat tekan yang didapatkan tidak berbeda jauh dengan kuat tekan paving block normal.

\section{Analisis Data HasilPengujian}

Data hasil pengujian dianalisis dengan menggunakan standar deviasi. Nilai standar deviasi yang semakin kecil memberikan gambaran bahwa nilai titik data individu mendekati dengan nilai rataratanya dan juga sebaliknya.

Nilai standar deviasi kuat tekan pada umur 7 hari lebih kecil dibandingkan dengan umur pavingblock lainnya. Nilai standar deviasi terkecil pada umur 7hari terdapat pada variasi0\% sebesar 1,55 yang menunjukkan nilai titik data individu mendekati nilai rataratanya. Peningkatan kuat tekan berturutturut yang terjadi pada variasi $2,5 \%, 5 \%$, $7,5 \%$ dan turun pada $10 \%$ masih berada pada batas bawah dan batas atas standar deviasi.Nilaistandar deviasiterbesar terdapatpadavariasi5\%padaumur28

harisebesar4,37yang berartinilaititikdata individu menjauhi nilai rata-ratanya.

\section{Kesimpulan}

1. Hasil kuat tekan rata-rata mengalami peningkatan berturut-turut pada variasi $0 \%, 2,5 \%, 5 \%, 7,5 \%$ dan turun pada $10 \%$.

2. Hasil kuat tekan rata-rata terbesar terjadi pada variasi 7,5\% yaitu pada umur 7 hari adalah sebesar 31,19 Mpa, umur 14 sebesar 33,10 Mpa dan umur 28 hari adalah sebesar 34,74 Mpa.

3. Persentase Peningkatan kuat tekan ratarata terbesar paving block terdapat pada variasi $7,5 \%$ yaitu pada umur 7 hari sebesar 21,65\%, umur 14 hari sebesar $20,94 \%$ danumur 28 hari sebesar 23,19\%.

\section{Saran}

1. Perlu dilakukan penelitian lebih lanjut mengenai penggantian sebagian semen dengan abu cangkang lokan dan fly ash terhadap kuat tekan paving block dengan variasi $10 \%$ hingga $30 \%$. 
2. Perlu dilakukan penelitian lebih lanjut mengenai uji absorsi dan lendutan pada pembuatan paving block.

3. Perlu dilakukan penelitian lebih lanjut mengenai variasi penekanan yang diberikan dalam pembuatan paving block.

\section{DAFTAR PUSTAKA}

Andre., 2012. Studi Sifat Mekanik Paving Block Terbuat Dari Campuran Limbah Adukan Beton dan Serbuk Kerang. Universitas Indonesia, Depok.

Armeyn., 2014, Kuat Tekan Beton dengan Fly Ash Ex. PLTU Sijantang Sawahlunto, Jurnal Momentum, Vol. 16, 24-33.

Hendriansyah., 2016. Pengaruh Penambahan Serbuk Cangkang Lokan Pada Pembuatan Paving Block Dengan Metode Mekanis Terhadap Kuat Tekan Paving Block. Universitas Bengkulu, Bengkulu.

Mulyati., Maliar, S., 2015. Pengaruh Penggunaan Fly Ash Sebagai Pengganti Agregat Terhadap Kuat Tekan Paving Block. Institut Teknologi Padang,Sumatra Barat.

Nurzal., dan Mahmud, J. 2013. Pengaruh Komposisi Fly Ash Terhadap Daya Serap Air Pada Pembuatan Paving block. Institut Teknologi Padang, Padang.

Pamungkas, B., dan Hairunnisa, S. 2007.

Komparasi Mutu Paving block Antara Metode Mekanis dan Konvensional dengan Campuran Endapan Sampah. Universitas Diponegoro, Semarang.

Sebayang, S., Diana, I.W.,danPurba, A. 2011. PerbandinganMutu Paving block Produksi Manual dengan
Produksi Masinal. Universitas Lampung, Bandar Lampung.

SNI 03-0691-1996. 1996. Bata Beton (Paving block). Badan Standardisasi Nasional, Jakarta.

SNI03-2847-2002.2002. Tata Cara

Perhitungan truktur Beton Untuk Bangunan Gedung. Departemen Pekerjaan Umum Yayasan Badan Penerbit PU, Bandung.

SNI 03-6815-2002. 2002. Tata Cara Mengevaluasi Hasil Uji Kekuatan Beton. Departemen Pekerjaan Umum Yayasan Badan Penerbit PU, Bandung.

SNI 15-2049-2004. 2004. Semen Portland, Departemen Pekerjaan Umum Yayasan Badan Penerbit PU, Bandung.

SNI 15-7064-2004., Semen Portland Komposit, Departemen Pekerjaan Umum Yayasan Badan Penerbit PU, Jakarta.

Wahyuni, A.S., Dlucef, A., Supriani, F., 2013. Pengaruh Penambahan Serat Bambu dan Pengganti 10\% Agregat Halus dengan Abu Sekam Padi dan Abu Cangkang Lokan Terhadap Kuat Tarik Beton. Universitas Bengkulu, Bengkulu. 